\title{
Clinicians' Overestimation of Their Geographic Service Area
}

Robert M. Rock, MD

Winston R. Liaw, MD, MPH ${ }^{2,3}$

Alex H. Krist, MD, MPH

Sebastian Tong, MD, MPH

David Grolling, MPS 5

Jennifer Rankin, $P b D^{5}$

Andrew W. Bazemore, MD, MSPH ${ }^{2}$

'Montefiore Medical Center, Department of Family and Social Medicine, Bronx,

New York

${ }^{2}$ University of Texas Health Science

Center at Houston, Houston, Texas

${ }^{3}$ The Robert Graham Center,

Washington, DC

${ }^{4}$ Virginia Commonwealth University, Department of Family Medicine and Population Health, Richmond, Virginia

${ }^{5}$ HealthLandscape/American Academy of Family Physicians, Leawood, Kansas

\begin{abstract}
In this study, we evaluated family physicians' ability to estimate the service area of their patient panel-a critical first step in contextual population-based primary care. We surveyed 14 clinicians and administrators from 6 practices. Participants circled their estimated service area on county maps that were compared with the actual service area containing $70 \%$ of the practice's patients. Accuracy was ascertained from overlap and the amount of estimated census tracts that were not part of the actual service area. Average overlap was $75 \%$, but participants overestimated their service area by an average of 166 square miles. Service area overestimation impedes implementation of targeted community interventions by practices.
\end{abstract}

Ann Fam Med 2019;17:S63-S66. https://doi.org/10.1370/afm.2383.

\section{INTRODUCTION}

$\mathrm{V}$ alue-based payment has led practices to implement a wide range of population health approaches. For many, the population includes only those patients coming to the clinic, with a focus on overdue reports and care coordination. For others, the focus extends beyond the clinic to include community linkages and interventions. Unfortunately, the knowledge, skills, and tools that practices need to undertake the latter activities are at varying stages of maturity. Only one-third of family physicians can even estimate the size of their patient panel. ${ }^{1}$ The percentage who can define the "community" they serve is likely lower, which ultimately leaves clinicians feeling unprepared. ${ }^{2}$

To address this gap, practices can implement community-oriented primary care (COPC), by executing 4 iterative steps: defining the community, identifying health problems, developing and implementing interventions, and conducting ongoing evaluation. ${ }^{3-5}$ Although COPC was developed in the 1940s, its adoption has been limited by fee-for-service arrangements and barriers to accessing population data. ${ }^{6,7} \mathrm{With}$ electronic health records (EHRs), advances in Geographic Information Systems (GIS), and value-based payment, these obstacles are less daunting, making COPC an attractive framework for population health. ${ }^{8-10}$ In this study, we used GIS to evaluate the ability of a group of family physicians to define their patient community - the first step of a practicewide effort to use COPC for practice transformation.

\section{METHODS}

Conflicts of interest: authors report none.

\section{CORRESPONDING AUTHOR}

Robert M. Rock, MD

3544 Jerome Ave

Bronx, NY 10467

robertmichaelrock@gmail.com
This study took place at 6 northern Virginia family medicine practices. We recruited 14 clinicians, 6 care management staff, 4 patients, and 3 administrators. Of these, 8 clinicians and 1 administrator submitted drawings. To incorporate the perspectives of trainees, we additionally recruited 5 third-year residents.

Study facilitators described to participants the definition of and method for calculating a clinic's service area. We defined the service area 
as the geographic area containing $70 \%$ of each practice's patients and explained that the service area was calculated by listing all the census tracts in which a practice's patients live and rank-ordering them from most to least. On a map centered on Fairfax County, Virginia, we then instructed participants, "Circle areas that you think represent your practice's service area." We collected participants' sketches of their perceived service area. For each practice, we then compared the perceived service area with the actual service area, which was created by geocoding the home addresses listed in the EHR of patients making at least 1 office visit between January 1, 2012 and January 1, 2015.

The primary outcome measure was the accuracy of the perceived service area as compared with the actual service area. We entered each participant's perceived service area sketch into ArcMap 10.3.1 (Esri) and used the ModelBuilder tool in ArcMap to construct maps using the perceived and actual service areas as separate layers. We quantified the digitized perceived and actual service areas to calculate the area in census tracts and square miles, and compared overlap between the 2 areas, the number of core tracts missing from the perceived service area, and the number of noncore sketched tracts that were included in the perceived service area. Overlapping tracts were calculated by selecting all perceived service area tracts that were found within the actual service area and dividing them by the total number of tracts in the actual service area. Noncore tracts included were calculated as the number of perceived service area tracts that were not part of the actual service area, divided by the total number of tracts in the perceived service area. Core tracts missed were calculated as the percentage of actual service area tracts that were not captured by the participants' perceived service area.

The study was approved by the Institutional Review Board of Virginia Commonwealth University.

\section{RESULTS}

One-half of the participants included more than $75 \%$ of their actual service area in their perceived service area sketch (Table 1). The perceived service area sketches were generally much larger than the actual service areas and tended to include large numbers of census tracts not in the actual service area.

On average, more than $50 \%$ of the census tracts included in the perceived service area sketches were not part of their respective actual service areas. The average amount of overestimation was approximately 165.9 square miles (112.1\% of the actual service area), which suggests that participants perceived their patient

Table 1. Accuracy of Perceived Service Area vs Actual Service Area, by Practice

\begin{tabular}{|c|c|c|c|c|c|c|c|c|c|c|c|}
\hline \multirow[b]{2}{*}{$\begin{array}{l}\text { Practice and } \\
\text { Participant }\end{array}$} & \multirow{2}{*}{$\begin{array}{l}\text { Total } \\
\text { Census } \\
\text { Tracts }\end{array}$} & \multirow[b]{2}{*}{$\begin{array}{l}\text { Square } \\
\text { Miles }\end{array}$} & \multicolumn{3}{|c|}{ Overlap } & \multicolumn{3}{|c|}{ Core Tracts Missed } & \multicolumn{3}{|c|}{$\begin{array}{l}\text { Noncore Tracts } \\
\text { Included }\end{array}$} \\
\hline & & & $\begin{array}{l}\text { Census } \\
\text { Tracts }\end{array}$ & $\begin{array}{l}\text { Square } \\
\text { Miles }\end{array}$ & $\begin{array}{l}\text { Percent } \\
\text { of Actual }\end{array}$ & $\begin{array}{l}\text { Census } \\
\text { Tracts }\end{array}$ & $\begin{array}{l}\text { Square } \\
\text { Miles }\end{array}$ & Percent & $\begin{array}{l}\text { Census } \\
\text { Tracts }\end{array}$ & $\begin{array}{l}\text { Square } \\
\text { Miles }\end{array}$ & Percent \\
\hline Practice 1 & 97 & 228.8 & $\ldots$ & $\ldots$ & $\ldots$ & $\ldots$ & $\ldots$ & $\ldots$ & $\ldots$ & $\ldots$ & $\ldots$ \\
\hline Physician 1 & 191 & 417.9 & 94.0 & 212.6 & 96.9 & 3.0 & 16.2 & 3.1 & 97.0 & 205.2 & 50.8 \\
\hline Physician 2 & 499 & 969.0 & 97.0 & 228.8 & 100.0 & 0.0 & 0.0 & 0.0 & 402.0 & 740.1 & 80.6 \\
\hline Resident 3 & 127 & 222.4 & 77.0 & 153.2 & 79.4 & 20.0 & 75.6 & 20.6 & 50.0 & 69.2 & 39.4 \\
\hline Physician 4 & 196 & 231.2 & 71.0 & 113.7 & 73.2 & 26.0 & 115.2 & 26.8 & 125.0 & 117.6 & 63.8 \\
\hline Physician 5 & 139 & 363.1 & 87.0 & 211.0 & 89.7 & 10.0 & 17.9 & 10.3 & 52.0 & 152.2 & 37.4 \\
\hline Resident 6 & 135 & 216.7 & 69.0 & 141.4 & 71.1 & 28.0 & 87.5 & 28.9 & 66.0 & 75.3 & 48.9 \\
\hline Practice 2 & 55 & 111.2 & $\ldots$ & $\ldots$ & $\ldots$ & $\ldots$ & $\ldots$ & $\ldots$ & $\ldots$ & $\ldots$ & $\ldots$ \\
\hline Physician 1 & 33 & 35.1 & 30.0 & 30.9 & 54.5 & 25.0 & 80.3 & 45.5 & 3.0 & 42.0 & 9.1 \\
\hline Practice 3 & 15 & 86.8 & $\ldots$ & $\ldots$ & $\ldots$ & $\ldots$ & $\ldots$ & $\ldots$ & $\ldots$ & $\ldots$ & $\ldots$ \\
\hline Administrator 1 & 46 & 357.8 & 14.0 & 64.1 & 93.3 & 1.0 & 22.7 & 6.7 & 32.0 & 293.7 & 69.6 \\
\hline Physician 1 & 42 & 436.4 & 15.0 & 86.8 & 100.0 & 0.0 & 0.0 & 0.0 & 27.0 & 349.7 & 64.3 \\
\hline Practice 4 & 38 & 167.1 & $\ldots$ & $\ldots$ & $\ldots$ & $\ldots$ & $\ldots$ & $\ldots$ & $\ldots$ & $\ldots$ & $\ldots$ \\
\hline Physician 1 & 119 & 400.7 & 38.0 & 167.1 & 100.0 & 0.0 & 0.0 & 0.0 & 81.0 & 232.9 & 68.1 \\
\hline Practice 5 & 38 & 84.5 & $\ldots$ & $\ldots$ & $\ldots$ & $\ldots$ & $\ldots$ & $\ldots$ & $\ldots$ & $\ldots$ & $\ldots$ \\
\hline Physician 1 & 85 & 71.9 & 13.0 & 15.6 & 34.2 & 25.0 & 68.9 & 65.8 & 72.0 & 56.3 & 84.7 \\
\hline Practice 6 & 32 & 149.9 & $\ldots$ & $\ldots$ & $\ldots$ & $\ldots$ & $\ldots$ & $\ldots$ & $\ldots$ & $\ldots$ & $\ldots$ \\
\hline Physician 1 & 38 & 259.3 & 20.0 & 90.3 & 62.5 & 12.0 & 59.7 & 37.5 & 18.0 & 169.1 & 47.4 \\
\hline Physician 2 & 18 & 272.0 & 13.0 & 97.9 & 40.6 & 19.0 & 52.0 & 59.4 & 5.0 & 174.1 & 27.8 \\
\hline $\begin{array}{l}\text { Nurse practi- } \\
\text { tioner } 3\end{array}$ & 28 & 427.4 & 19.0 & 111.6 & 59.4 & 13.0 & 38.3 & 40.6 & 9.0 & 315.8 & 32.1 \\
\hline
\end{tabular}


Figure 1. Examples of overlapping perceived and actual service areas.

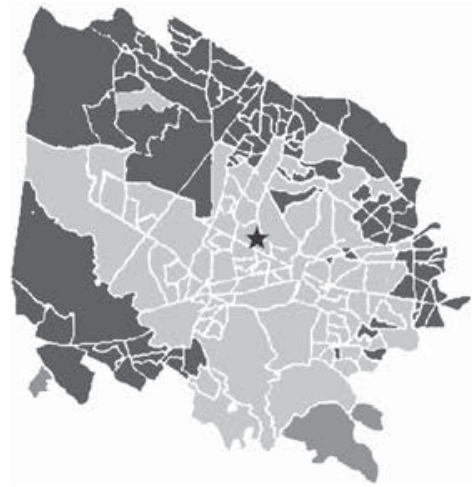

Sketch 1

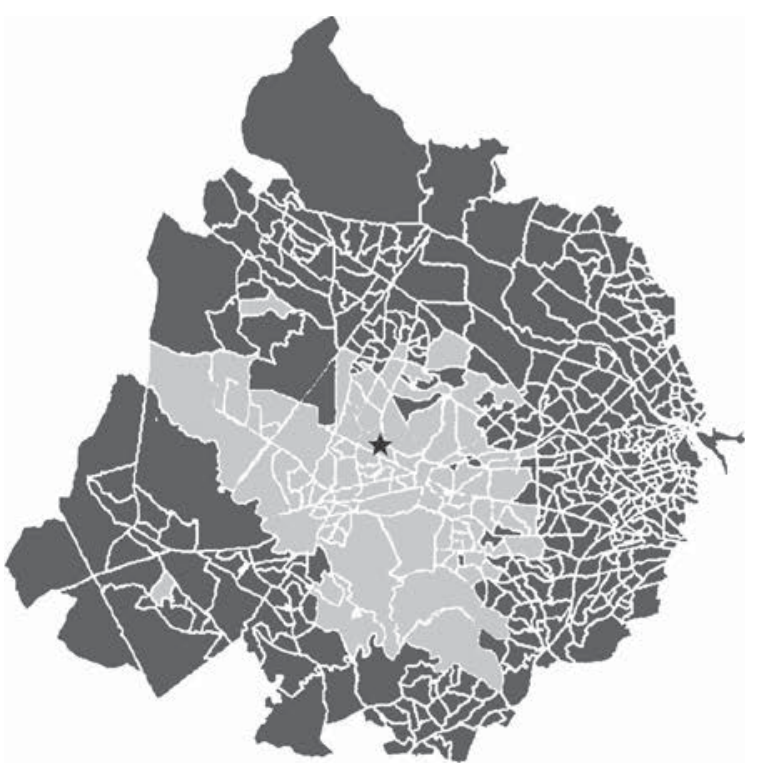

Sketch 2

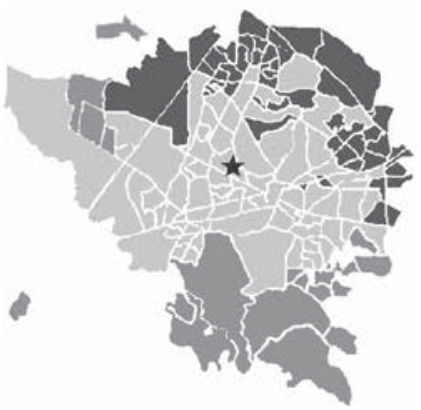

Sketch 3

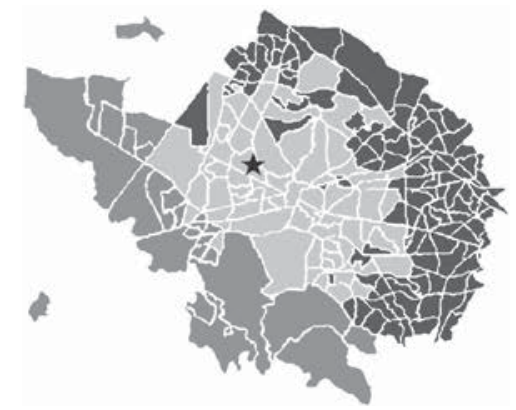

Sketch 4

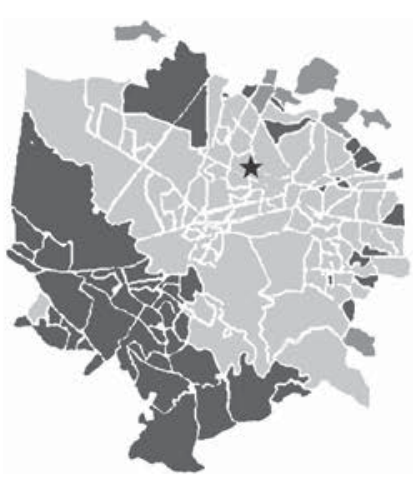

Sketch 5
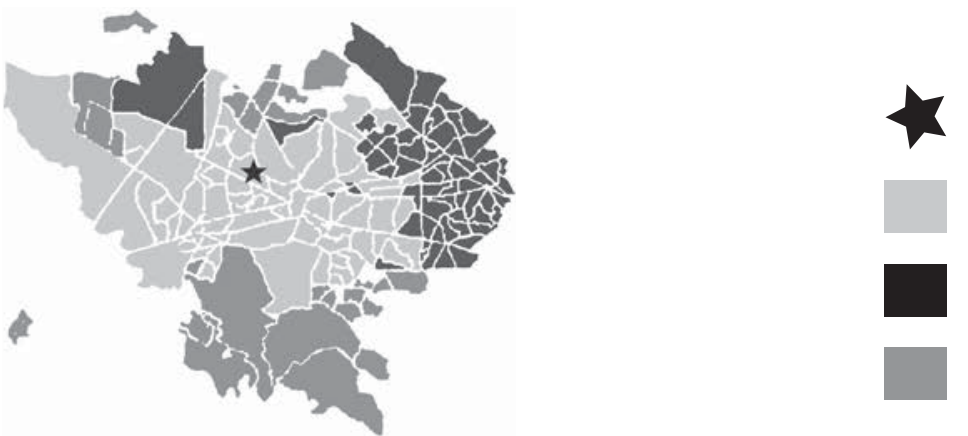

Practice

Overlapping census tracts

Perceived service area

Actual service area

Sketch 6

panels to be more widely distributed in the geographic region than they were.

There was considerable variability in how the perceived service area related to the actual service area geographically (Figure 1), although there was no discernible pattern or trend in directionality.

\section{DISCUSSION}

Most primary care clinicians and administrators could not accurately estimate their service area, overestimating the geographic footprint of their practice by $112 \%$ on average. Before practices can consider a COPCtype approach to community care, they first need to 
understand the community they serve. Sizable service area overestimations can make it more difficult for practices to understand their community's needs, identify those in need not accessing care, engage potential community partners for collaborative care, and consider novel community-based interventions. Knowing their service area is smaller than they thought may even make these tasks less daunting and more feasible.

The limitations inherent in this study provide opportunities for future studies. Other investigators can apply our methods in additional locations, testing our findings across a wide range of practice sizes, sociodemographic populations, population densities, and clinician participants.

Practices need tools to better understand the communities they serve before they can be expected to undertake population-level interventions. To effectively address the social determinants of their patients' health, it is imperative that primary care clinicians have highly granular and data-driven awareness of their practice community or service area. To do so efficiently, it is equally important that this awareness takes advantage of secondary data and techniques such as those presented here, and minimizes administrative burden in an era of increasing clinician burnout.

To read or post commentaries in response to this article, see it online at http://www.AnnFamMed.org/content/17/Suppl_1/S63.

Submitted August 18, 2018; submitted, revised, October 23, 2018; accepted December 13, 2018.

Key words: population health; geographic information systems; community-oriented primary care; outreach; practice-based research; professional practice; health information technology
Funding support: This research was supported by grant UL1TR000058 from the National Center for Advancing Translational Sciences and the CCTR Endowment Fund of Virginia Commonwealth University.

Previous presentations: Data were presented as an oral presentation during the American Public Health Association annual meeting; November 4-8, 2017; Atlanta, Georgia, and as a poster during the North American Primary Care Research Group annual meeting; November 17-21, 2017; Montreal, Canada.

\section{References}

1. Peterson LE, Cochrane A, Bazemore A, Baxley E, Phillips RL Jr. Only one third of family physicians can estimate their patient panel size. J Am Board Fam Med. 2015;28(2):173-174.

2. Robert Wood Johnson Foundation. Health Care's Blind Side: The Overlooked Connection Between Social Needs and Good Health. Princeton, NJ: Robert Wood Johnson Foundation; 2011.

3. Longlett SK, Kruse JE, Wesley RM. Community-oriented primary care: historical perspective. J Am Board Fam Pract. 2001;14(1):54-63.

4. Kark SL, Cassel J. The Pholela Health Centre: a progress report. 1952. Am J Public Health. 2002;92(11):1743-1747.

5. Mullan F, Epstein L. Community-oriented primary care: new relevance in a changing world. Am J Public Health. 2002;92(11): 1748-1755.

6. Nutting PA, Wood M, Conner EM. Community-oriented primary care in the United States: a status report. JAMA. 1985;253(12): 1763-1766.

7. Geiger HJ. Community-oriented primary care: the legacy of Sidney Kark. Am J Public Health. 1993;83(7):946-947.

8. Guagliardo MF. Spatial accessibility of primary care: concepts, methods and challenges. Int J Health Geogr. 2004;3(1):3.

9. Bazemore A, Phillips RL, Miyoshi T. Harnessing Geographic Information Systems (GIS) to enable community-oriented primary care. J Am Board Fam Med. 2010;23(1):22-31.

10. Mullan F, Phillips RL Jr, Kinman EL. Geographic retrofitting: a method of community definition in community-oriented primary care practices. Fam Med. 2004;36(6):440-446. 